\title{
EFFECT OF METHODS OF EXTRACTION ON PHYTOCHEMICAL CONSTITUENTS AND ANTIBACTERIAL PROPERTIES OF tetracarpidium conophorum SEEDS
}

\author{
S. P. MALU, G. O. OBOCHI, C. A. EDEM AND B. E. NYONG \\ (Received 20, June 2007; Revision Accepted 17, December 2008)
}

\section{ABSTRACTS}

Effect of methods of extraction on phytochemical constituents and antibacterial properties of the extracts of the seeds of tetracarpidium conophorum was studied. Different solvents extraction methods yielded varying amounts of the phytochemical constituents and the antibacterial screening showed that all the extracts except the water extracts have antibacterial activity. The inhibition of bacterial growth showed that the extracts were dose dependent since no inhibition occurred at lower concentration. The study therefore showed that the extracts of the seeds of tetracarpidium conopharum are dependent upon the solvent and methods of extraction, and that the extract possesses antibacterial properties, which could be useful in treatment of bacterial infections and or other related diseases.

KEY WORDS: Extraction methods, Chemical constituents, medicinal properties, tetracarpidium conophorum.

\section{INTRODUCTION}

Tetracarpidium conophorum (African walnut) belongs to the family of Euphorbiacea. It is a perennial woody climber commonly found in low bush especially in Africa, America, Europe and the Asia (Hutchinson and Dalzier, 1987). The leaves are globrous, ovate, long and margin toothed. The bases of the leaves are broaded and rounded up to the $5 \times 3$ inches with slender petioles up to 2 inches long. The fruits are four winged, ridged between wings and up to 3 inches in diameter. The seeds are edible even when raw. They have a bitter taste and a tonic effect like Kola. They can be eaten raw, cooked or with roasted corn. (Nuhu et al, 2002; Okerulu and Ani, 2001). The plant is known in Africa especially in Nigeria for its antibacterial efficacy, Decoction of the leaves and seeds serve as beverages, relieves abdominal pains and fever. The water extracts of the roots provides soothing beverage for fever and malaria infection (Nuhu et al, 2000; Balch and Balch, 2000). The method of extraction could affect the phytochemical contents and antibacterial properties of this medicinal plant. Therefore, the present study focused on the evaluation of the effects of extraction method on phytochemical constituents as well as the antibacterial properties of the seeds extracts.

\section{MATERIALS AND METHODS}

\section{Collection and treatment of samples}

The seeds of teracarpidium conophorum plant were obtained at the Marian Market (Calabar, Nigeria). The seeds were sun dried for seven days, shells removed, and ground into fine powder using an electric grinder. Then $100 \mathrm{~g}$ of the powdered mass obtained was stored in a clean sterile bottle at room temperature, and used for the various extractions.
The soxhlet ethanolic extract was obtained by soxhlet extraction of $20 \mathrm{~g}$ in $100 \mathrm{ml}$ of $95 \%$ ethanol at $78^{\circ} \mathrm{C}$ using soxhlet apparatus. The extract was then concentrated to $10 \mathrm{ml}$ on a water bath, and dried at room temperature. The $n$-hexane extract was obtained by dissolving $20 \mathrm{~g}$ of the powdered mass in $100 \mathrm{ml}$-hexane in a conical flask. The mixture was stirred, covered, allowed to stand for $24 \mathrm{hrs}$, and filtered using sterile Whatman No.42 filter paper. The bright yellow filtrate (extract) was concentrated to $10 \mathrm{ml}$ on a water bath, and evaporated to dryness at room temperature.

The ethylacetate, $95 \%$ ethanolic, and distilled water extracts were obtained by repeating the above procedure for $n$-hexane extract. The $n$-hexane, ethanol and soxhlet extracts were light brown in colour while the water extract was pale yellow. The various extracts obtained were then used for determination of phytochemical contents (i.e. steroids, alkaloids, tannins, saponnins and flavonoids) as well as antibacterial analysis.

\section{Estimation of phytochemical contents}

\section{Qualitative test for steroids}

$2.0 \mathrm{ml}$ of acetic anhydride was added to $0.15 \mathrm{~g}$ of each sample extract, mixed and then $2.0 \mathrm{ml}$ of $1 \mathrm{~N}$ $\mathrm{H}_{2} \mathrm{SO}_{4}$ was added. The colour changed from violet to blue in the sample, indicating absence of steroids.

\section{Estimation of alkaloids contents}

The alkaloid content of each extract was determined by the method of Harborne (1973). About $5.0 \mathrm{~g}$ of each sample was weighed into a $250 \mathrm{ml}$ beaker, and a $200 \mathrm{ml}$ of $10 \%$ acetic acid in ethanol was added, and allowed to stand for $4 \mathrm{hrs}$. This was filtered using whatmann No.42 filtered paper, concentrated in water bath to $1 / 4(50 \mathrm{ml})$ of the original volume. Then, concentrated $\mathrm{NH}_{4} \mathrm{OH}$ was added dropwise to each

S. P. Malu, Department of chemistry / Biochemistry, Cross River University of Technology, Calabar.

G. O. Obochi, Department of chemistry / Biochemistry, Cross River University of Technology, Calabar.

C. A. Edem, Department of Pure and Applied chemistry, University of Calabar.

B. E. Nyong, Department of chemistry / Biochemistry, Cross River University of Technology, Calabar. 
extract until the precipitate was complete. The suspension was allowed to settle and the precipitate was collected, washed with $\mathrm{NH}_{4} \mathrm{OH}$ and then filtered. The residue was dried and weighed. The percentage alkaloid was then calculated.

\section{Estimation of tannin content}

Tannin content was determined by the method of Van Burden and Robinson (1981). 500mg of each sample extract was weighed into a $50 \mathrm{ml}$ plastic bottle,50ml distilled water added, shaken for $1 \mathrm{hr}$ in a mechanical shaker, filtered into a $50 \mathrm{ml}$ volumetric flask, and made up to the mark with distilled water. Then $5.0 \mathrm{ml}$ of each sample was mixed with $2.0 \mathrm{ml}$ of $0.1 \mathrm{M} \mathrm{FeCl}_{3}$ in $0.1 \mathrm{~N} \mathrm{HCl}$ and $0.008 \mathrm{M}$ potassium ferricynide was added, allowed to stand for 10 minutes and the absorbance read at 120 $\mathrm{nm}$ in $6400 / 6400$ spectrophotometer(Jenway,Essex,England).

\section{Estimation of saponin content}

Saponin content was determined by the method of Obadoni and Chuko (2001). About 2.0g of each extract was mixed with $100 \mathrm{ml}$ of $20 \%$ ethanol, and were incubated in a water bath at $55^{\circ} \mathrm{C}$ for $4 \mathrm{hrs}$ with stirring. The mixture was filtered and the extract was reextracted with $200 \mathrm{ml}$ of $20 \%$ ethanol. The combined extract was concentrated to $40 \mathrm{ml}$ in a water bath at $90^{\circ} \mathrm{C}$. The concentrate was then transferred into a $20 \mathrm{ml}$ separatory funnel and $20 \mathrm{ml}$ diethyl ether was added, and shaken vigorously. The aqueous layer was recovered while the ether layer was discarded, the purification process was heated and $60 \mathrm{ml}$ of $\mathrm{n}$-butanol added. The combined n-butanol extracts were washed twice with $10 \mathrm{ml}$ of $5 \%$ aqueous $\mathrm{NaCl}$, and the remaining solution was heated in a water bath. After evaporation, the samples were dried in the oven to a constant weight, and the percentage saponnin content was calculated.

\section{Estimation of flavonoid content}

The flavonoid content of the extracts was estimated by the method of Boham and Kopicalabyazen (1974). About $1.0 \mathrm{~g}$ of each sample was extracted repeatedly with $100 \mathrm{ml}$ of $80 \%$ methanol. The whole solution was then filtered through Whatmann No.42 filtered paper. The filtrate was transferred into a crucible and evaporated to dryness on a water bath, and weighed. The percentage flavonoid content was then calculated.

\section{Estimation of Glycosides}

The glycosides content of the extracts was determine by dissolving $10.0 \mathrm{~g}$ of the extracts in $100 \mathrm{ml}$ of $50 \% \mathrm{H}_{2} \mathrm{SO}_{4}$ in test tubes. The mixture was heated in boiling water for 15 minutes, and $10 \mathrm{ml}$ of Fehling solution added, and the mixture boiled. A red precipitate in each extract tested, indicated the presence of glycosides. The percentage glycoside was calculated.

\section{Antibacterial screening}

The antibacterial analysis was carried out by the disc diffusion method of Kirby Bauer described by Duguid et al, (1989). This method determines the antibacterial activity of the extracts. The method involves preparation of nutrient medium, culture and inoculation. The inoculated extracts were then diluted serially and examined for inhibition zones. The presence of zones of inhibition indicates activity.

\section{Preparation of the nutrient medium}

Nutrient agar medium was prepared by dissolving $2.8 \mathrm{~g}$ of nutrient agar in $100 \mathrm{ml}$ distilled water. The solution was sterized in an autoclave at $121^{\circ} \mathrm{C}$ at $1.1 \mathrm{~N}$ pressure for $15 \mathrm{~min}$. the suspension was cooled and poured into sterile Petri-dishes to solidify. The agar depth of the medium was $4 \mathrm{~mm}$.

\section{Preparation of cultures and inoculation \\ Pure cultures of coliform bacillus,} staphylococcus epidermidis and streptococcus viridians obtained from the microbiology laboratory, Cross River University of Technology, Calabar, Nigeria, were separately used to inoculate the Petri-dishes. This was done by streaking the surface of the plates in a zig zag manner until the entire surface was covered. The inoculated plates were then incubated at room temperature for $24 \mathrm{hrs}$.

\section{Assay of extracts}

The extracts were serially diluted to obtain $1.0 \%, 0.5 \% .0 .25 \%$ and $0.125 \%$ solutions of the extracts in sterile test tubes. Sterilized $9 \mathrm{~mm}$ filter paper discs soaked in the dilute extracts were placed on the plates and incubated for $24 \mathrm{hrs}$. at room temperature. The plates were examined for clear zones of inhibition. Presence of zones of inhibition indicated activity. The zones were measured.

\section{Estimation of Glycosides RESULTS}

Table 1 presents the results of the phytochemical constituents of the seeds of tetracarpidium conophorum. The results showed that alkaloids, tannins, saponnins, flavanoids and glycosides are present in the extracts. The results showed that the soxhlex extraction methods has the highest content of tannins, flavonoids, alkaloids, saponins and glycosides $(42.2 \pm 0.42, \quad 41.21 \pm 0.41,40.34 \pm 0.51,31.28 \pm 0.34$ and $20.17 \pm 0.17 \pm 0.24)$ respectively. The ethanolic extraction method came second in content of tannins alkaloids, flavonoids, saponins and glycosides $(33.21 \pm 0.38,32.83 \pm 0.21,32.23 \pm 0.34,30.11 \pm 0.32$, and

$20.13 \pm 0.20)$ respectively. This was followed by the ethyl acetate extraction methods with higher values in glycosides and saponins. Water extraction methods came fourth with higher values in glycosides and saponin content. Generally there was no significant difference $(p>0.05)$ in the glycosides contents in the extracts obtained from all the different solvent extraction methods.

Table 2 presents the results of antibacterial activity. The results showed that all the extracts except the water extract have antibacterial activity. Table 3 presents the results of inhibition of bacterial growth by the extracts. The results showed that the effects of the extracts are dose dependent since no activity was observed at very low concentrations. Also the results showed that higher dose of the extract will be useful in the treatment of bacterial infections. Further, the steroid extracts of these seeds can be useful in the regulation of reproductive 
system particularly as sex hormones and $d$ could be

useful in the correction of impotence.

Table 1: Phytochemical contents of the extracts of the seeds of teracarpidium conophorum

\begin{tabular}{|l|l|l|l|l|l|}
\hline Extract & Alkaloids (\%) & Tannins (\%) & $\begin{array}{l}\text { Flavonoids } \\
(\mathbf{\%})\end{array}$ & $\begin{array}{l}\text { Saponnins } \\
(\mathbf{\%})\end{array}$ & $\begin{array}{l}\text { Glycosides } \\
(\mathbf{\%})\end{array}$ \\
\hline n-Hexane & $8.36 \pm 0.24$ & $7.14 \pm 0.22$ & $8.12 \pm 0.25$ & $12.24 \pm 0.22$ & $19.23 \pm 0.21$ \\
\hline Ethyl acetate & $9.54 \pm 0.21$ & $9.13 \pm 0.20$ & $9.21 \pm 0.24$ & $12.23 \pm 0.26$ & $19.24 \pm 0.18$ \\
\hline Ethanol & $32.83 \pm 0.21$ & $33.21 \pm 0.38$ & $32.23 \pm 0.34$ & $30.11 \pm 0.32$ & $20.13 \pm 0.20$ \\
\hline Soxhlet & $40.34 \pm 0.54$ & $42.21 \pm 0.42$ & $41.21 \pm 0.41$ & $31.28 \pm 0.34$ & $20.17 \pm 0.24$ \\
\hline Water & $8.93 \pm 0.18$ & $8.13 \pm 0.21$ & $9.23 \pm 0.24$ & $13.20 \pm 0.23$ & $21.23 \pm 0.20$ \\
\hline
\end{tabular}

Table 2: The antibacterial activity of the extracts of the seeds of tetracarpidium conophorum

\begin{tabular}{|l|c|c|c|c|c|}
\hline Test organism & n-Hexane & Ethylacetate & Ethanol & Soxhlet & Water \\
\hline Coliform bacillus & - & + & + & + & - \\
\hline $\begin{array}{l}\text { Straphylococcus } \\
\text { epidermis }\end{array}$ & + & + & + & + & - \\
\hline $\begin{array}{l}\text { Streptococcus } \\
\text { viridans }\end{array}$ & + & + & + & + & - \\
\hline
\end{tabular}

$+=$ active

- = not active.

Table 3: Inhibition of bacterial growth by the extracts of the seeds of tetracarpidium conophorum

\begin{tabular}{|c|c|c|c|c|c|c|}
\hline \multirow[t]{2}{*}{ Test organism } & \multirow{2}{*}{$\begin{array}{l}\text { Dilution } \\
(\%)\end{array}$} & \multicolumn{5}{|c|}{ Zone of inhibition (mm) } \\
\hline & & n-hexane & Ethyl acetate & Ethanol & Soxhlet & Water \\
\hline \multirow[t]{4}{*}{ Coliform bacillus } & 1.00 & & 4.0 & 5.0 & 6.0 & \\
\hline & 0.50 & & 2.5 & 3.0 & 4.5 & \\
\hline & 0.25 & & & & & \\
\hline & 0.125 & & & & & \\
\hline \multirow{4}{*}{$\begin{array}{l}\text { Straphylococcus } \\
\text { epidermis }\end{array}$} & 1.00 & $3.0 \overline{0}$ & 5.0 & 5.5 & 7.0 & \\
\hline & 0.50 & 1.0 & 3.0 & 3.5 & 4.0 & 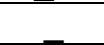 \\
\hline & 0.25 & & 1.5 & & & \\
\hline & 0.125 & & & & & \\
\hline \multirow{4}{*}{$\begin{array}{l}\text { Streptococcus } \\
\text { viridans }\end{array}$} & 1.00 & 6.0 & 5.5 & 6.0 & 6.5 & \\
\hline & 0.50 & 3.5 & 3.0 & 3.0 & 3.5 & \\
\hline & 0.25 & . & . & $=$ & $=$ & \\
\hline & 0.125 & & & & & \\
\hline
\end{tabular}

\section{DISCUSSION}

The phytochemical screening and quantitative estimation of the percentage crude yield of phytochemical constituents of the extracts of the seeds of tetracarpidium showed that the seeds are rich in alkaloids, flavonoids, tannins, saponnins and glycosides; and also possess antibacterial properties as well as physiological activity (Sofowora, 1993; Ekam and Ebong, 2007). Flavonoids are most commonly known for their antioxidant activity. They are modifiers which modify the body's reactions to allergens, viruses, and carcinogens. They show anti-allergic, anti-inflammatory, antimicrobical and anticancer activity (Balch and Balchi, 2000; Ekam and Ebong, 2007), and may be useful in therapeutic roles (Jisika et al, 1992). Alkaloids are organic compounds that contain nitrogen, and are physiologically active with sedative and analgesic properties. They are used in relieving pains, anxiety and depression (Jisika et al, 1992). Alkaloids are toxic due to their stimulatory effects, leading to excitation of cells and neurological dysfunction (Obochi, 2006; Ekam and Ebong, 2007).

Glycosides are compounds containing a carbohydrate and non-carbohydrate residue (moiety) in the same molecule. In these compounds, the carbohydrate moiety is attached by an acetal linkage of carbon-1 to the non-carbohydrate residue (aglycone). They all contain steroid as aglycone component in combination with sugar molecules. They are important in medicine because of their action on heart and are used in cardiac insufficiency (Balch and Balch, 2000). Thus, cardiac glycosides are drugs and can be used in the treatment of congestive heart failure and cardiac arrhythmia. They work by inhibiting the $\mathrm{Na}^{+} / \mathrm{Na}^{+}$pump, resulting in an increase in the levels of sodium ions in the myocytes, which then leads to a rise in the level of calcium ions. This inhibition increases the amount of $\mathrm{Ca}^{2+}$ ions available for concentration of the heart muscle, improves cardiac output and reduces distention of the heart (Bertorello et al, 1990; Clausen and Nielson, 1994; Beltowski et al, 1998). These glycosides are found 
as secondary metabolites in several plants and animals (Clausen, 1996; Beltowski et al, 1998).

However, some glycosides, such as ouabain, are toxic as it inhibits active transport of $\mathrm{Na}^{+}$in cardiac muscle (sodium pump inhibitor), resulting in inhibition of translocases during electron transport chain, and leading to death (Beltowski et al, 1998). Also phloridzin (toxic glycosides) blocks the transport of sugar across the mucosal cells of small intestine and also renal tubular epithelium; it displaces $\mathrm{Na}^{+}$from the binding sites of carrier protein and prevents the binding of sugar molecule and produces glycosuria (Clausen, 1994; Gloor, 1997; Beltowski et al, 1998).

Tannins (tannic acids) and saponnins are responsible for the antibacterial activity of the plant seed extracts (Gloor, 1997). Saponnins are used in veterinary vaccines as adjuvant (e.g. foot-and-mouth disease vaccines) helping to enhance immune response. They are also mild detergents and can be used commercially as well as for research (Belch and Belch, 2000). They can also be used in intracellular histochemistry staining to allow antibody access to intracellular proteins (Belch and Belch, 2000). Also, because of its ability to permeate cells without destroying cell morphology, it is used in laboratory applications to treat live cells in order to facilitate peptide or reagents such as antibodies entering cells instead of the detergents (Belch and Belch, 2000).

The results in this study have shown that different solvent extraction method affect changes in the content of the extracts depending on the solvent used as well as the method of extraction. The results for antibacterial screening have shown that all the extracts except the water extract have antibacterial activity. The antibacterial activity is due mainly to the presence of tannins and saponnins (Okerulu and Ani, 2001). The results of the inhibition of bacterial growth have shown that the effects of the extracts appear to be effective at higher concentration since no activity was observed at very low concentration. The soxhlet extract was found to be the most effective, appears to be non-target specific; and can be beneficial in the treatment of bacterial infections.

In conclusion, this study has shown that the phytochemical contents of the extracts of the seeds of tetracarpidium conophorum are dependent upon the solvent and method of extraction. The results have also shown that these extracts possess antibacterial properties and that the inhibition of bacterial growth was dose dependent. The results of this study may suggest these extracts may be useful in the treatment of bacterial infections and other related diseases as well as enhancing immune responses.

\section{REFERENCES:}

Balch, J.F and Balch, P.A., 2000.Prescription for Nutritional Healing. New York: A very, Penguin Putnam Inc.pp.267-270.

Beltowski, J, Gorny, D and Marciniak, A., 1998. The mechanism of $\mathrm{Na+} \mathrm{K}+-\mathrm{ATpase}$ inhibition by artrial nattruiretic factor in rat and medulla. Journal of physiological pharmacology 49:271283.
Bertorello, A and Aperia, A., 1990. Short term of $\mathrm{Na+}$ K+-ATPase activity by dopamine. American Journal of Hypertension 3:515-545.

Clausen, $\mathrm{T}$ and Nielson,O. B., 1994. The Na+-K+ATPase and muscle contractivity.Acta Physio. Scander 152:365-375.

Clausen, T., 1996. The $\mathrm{Na}^{+}-\mathrm{K}^{+}-$ATPase in skeletal muscle; Quantification, regulation and function significance. Acta. Physiol. Scand 156:227-235.

Duguid, J.P., Marmoid, B.P. and Swain, R.H.A., 1989. Mackie and McCartney's Medical Microbiology.Vol.1.13 ${ }^{\text {th }}$ Edition. Churchill Livingstone London.163.

Gloor, S .M., 1997. Relevance of Na+-K+-ATPase to local extracellular potassium homeostasis and modulation of synaptic transmission. FEBS Lett 412:1-4.

Harbone, J. B., 1973. Phytochemical methods. A guide to modern Techniques of plant Analysis.Chapman and Hall, London.267-270.

Hutchinson, J and Dalziel, J. M., 1987. Flora of west Tropical Africa.2 ${ }^{\text {nd }}$ Edition. Part 1\&2. (2)111-112.

Jisika, M., Ohigashi, H., Nogaka, H., Tada, T., and Hirota, M., 1992. Bitter steroid glycosides, Vernon sides $A 1, A 2$, and $A 3$ and related $B 1$ from the possible medicinal plant vernonia amygdalina used by wild Chimpanzees. Tetrahedron, 48:625-630.

Nuhu, A.M., Mshelia.M.S. And Yakubu, Y., 2000. Antimicrobial screening of the bark extract of pterocarpus erinaceous tree. Journal chemical Society of Nigeria.25:85-92.

Obadoni, B.O., and Ochuka, P. O., 2001. Phytochemical studies and comparative efficacy of the crude extracts of some homeostatic plants in Edo and Delta States of Nigeria. Global Journal of Pure and Applied Science 8:203-208.

Okwu, D. E., 2001. Evaluation of the chemical composition of indigenous spices and flavoring agents. Global Journal of Pure and Applied Science 7(3):455-459.

Sofowora, A., 1993. Medicinal plants and traditional medicine in Africa. Spectrum books Ltd.Ibadan, Nigeria.289.

Van-Burden, T.P., Robinson, W.C., 1981. Formation of complexes between protein and tannic acid. Journal of Agricultural Food Chemistry.1:77. 